\title{
ESTIMATION OF WINTER RYE (Secale cereale L.) SUSCEPTIBILITY TO INFECTION BY POWDERY MILDEW (Blumeria graminis F. sp. secalis)
}

\author{
Henryk Bujak, Andrzej Jurkowski ${ }^{1}$ \\ Department of Genetics, Plant Breeding and Seed Production, Wrocław University of Environmental and Life Sciences \\ pl. Grunwaldzki 24A, 53-363 Wrocław, Poland \\ ${ }^{1}$ Department of Biotechnology, University of Zielona Góra \\ Prof. Z. Szafrana 1, 65-516 Zielona Góra, Poland \\ e-mail: andrzej.jurkowski@wp.pl
}

Received: 26.07 .2012

\section{Abstract}

In cold and wet years, powdery mildew (Blumeria graminis) causes losses in the yield of winter rye (Secale cerale L.) amounting to $20 \%$. In order to control the incidence of this disease and reduce the use of fungicides, it is recommendable to grow winter rye cultivars that are resistant or tolerant to infection by Blumeria graminis. The first step in the programmes of resistance-oriented cultivation of winter rye is the choice of adequate components for crossing. Such components should be characterized by resistance to powdery mildew infection, a trait which would be passed onto the new genotypes to be obtained.

The paper discusses the outcome of research aimed at selecting inbred lines of winter rye distinguishable by the lowest susceptibility to infection by Blumeria graminis. The evaluation covered 233 winter rye genotypes which had been inoculated with a field population of the pathogen mentioned. The level of infection was defined in a five-point scale from 0 to 4 (the authors' own scale). Next, the results were analyzed statistically. The genotypes under study were divided using Duncan's test into homogeneous groups. Seven such groups were distinguished. The first homogeneous group, of the lowest level of infection, comprised five inbred lines of rye. These lines can serve as components for crossing experiments in programmes of resistance-oriented breeding.

Key words: secale cereale, inbred lines, powdery mildew, resistance

\section{RUNNING HEAD: WINTER RYE SUSCEPTIBILITY TO POWDERY MILDEW}

\section{INTRODUCTION}

Winter rye (Secale cereale L.) occupies the second position in terms of area under cultivation in Poland and is also one the most important cereal species used in food industry. Powdery mildew, a disease caused by Blumeria graminis, can cause substantial yield losses, reaching $20 \%$, under conditions favourable to the development of this pathogen. The negative impact of powdery mildew infection on the yielding ability of the crop is particularly significant in the case of cultivars characterized by a shortened leaf [1]. This is so because with leaf shortening the proportion of leaves in the general assimilation balance increases in this species [2-4].

Of the eight special forms known in the population of Blumeria graminis species, four, namely B. graminis f. sp. hordei, B. graminis f. sp. tritici, B. graminis f. sp. secalis, and B. graminis f. sp. avenae, infect cereal plants. The above-mentioned forms are specialized to invade species from the genera, respectively, Hordeum, Triticum, Secale, and Avena [5,6].

Among the currently applied methods which control the development of this disease in cereal cropping, the most profitable and environmentally friendly is breeding and cropping of cultivars resistant or tolerant to the pathogen in question $[7,8]$.

In Poland rye is still cultivated over a large area, and therefore an attempt has been undertaken to assess a collection of available inbred lines with respect to their resistance to powdery mildew (B. graminis f. sp. Secalis). Lnbred lines defined as highly resistant to invasion by powdery mildew can serve as initial forms in the programmes of breeding hybrid cultivars and open-pollinated varieties.

\section{MATERIALS AND METHODS}

The research material was consisted of 233 inbred lines of winter rye Secale cereale L.comprised in 
the collection owned by the Department of Genetics, Plant Breeding and Seed Production at the Wrocław University of Environmental and Life Sciences. These are lines of various degrees of inbreeding, from 9 to 34 , and of different genetic origin.

The susceptibility of the rye genotypes to infection by Blumeria graminis f. sp. secalis was assessed in a glasshouse test. The infection experiment was carried out with the use of own field population of the pathogen. Pathogen populations were kept on seedlings of breeding origin (family) sensitive to infection by Blumeria graminis (the name was not given, not published). Inoculation was done at the 3-leaf stage by the brush method, bringing spores from infected seedlings onto tested plants (own method). Ten plants of every inbred line were inoculated. 'Bosmo' and 'Dańkowskie Diament' varieties were the control. Next, the plants were placed in a cabin with high humidity until the time of estimation of the infection level. The level of plant infection was estimated after seven days from inoculation applying a five-point scale (0-4), where 0 meant no symptoms of infection; 1 - resistant - visible chloroses and necroses; 2 - moderately resistant - poorly developed mycelium without sporulation, single chloroses and necroses; 3 - moderately susceptible - medium growth of mycelium and sporulation; 4 susceptible - well-developed mycelium and abundant sporulation. Lines estimated in the range of $0-2$ were treated as resistant.

\section{RESULTS}

In the glasshouse trial performed, the estimation of susceptibility to infection by Blumeria graminis f. sp. secalis covered 233 genotypes in total. The mean degree of infection of the studied rye material was found significantly different, amounting to 1-3.3 (according to the applied five-point scale mentioned above). The mean results of the assessment of the examined genotypes are shown in Table 1.

The observations of disease symptoms were carried out in a scale ranging from 0 to 4 . Since the observations made a discontinuous sequence of values, transformation of the results was performed with a view to obtaining continuity of the distribution and normal distribution. The raw results were transformed and the transformed results were used in the statistical analysis. In order to verify the significance of the variation in the winter rye material studied with respect to resistance to powdery mildew, one-way analysis of variance was performed for a completely randomized design. The mean squares from variance analysis allowed us to reject the null hypothesis which assumes that all genotypes are characterized by equal susceptibility to powdery mildew infection. And thus, in the winter rye forms under analysis different susceptibility to infection has been revealed (Table 2). Based on the mean values of infection, the studied rye genotypes have been divided into homogeneous groups, with Duncan's test used for that purpose. Seven homogeneous groups have been distinguished among the winter rye lines examined (Table 3 ). The first uniform group, resistant to infection by powdery mildew, is composed of five lines: UP77, UP78, UP2, UP76, UP90. For two of these lines (UP77, UP78), the average estimate of infection with powdery mildew is 1 . The second group comprises a few treatments which overlap the first group and are also characterized by good resistance to infection. 165 genotypes which are the most susceptible to powdery mildew infection have been included in the last homogeneous group. They include genotypes highly susceptible to infection by powdery mildew, with the average infection level reaching 3.3.

Table 1

Average level of infection of the studied rye material by powdery mildew (Blumeria graminis) under glasshouse conditions

\begin{tabular}{cc}
\hline $\begin{array}{c}\text { Average level } \\
\text { of infection }\end{array}$ & Lines (\%) \\
\hline 1 & 0.86 \\
1.3 & 1.29 \\
1.63 & 1.72 \\
2 & 1.29 \\
2.31 & 4.72 \\
2.64 & 19.31 \\
3 & 68.66 \\
3.32 & 2.15 \\
\hline
\end{tabular}

Table 2

Analysis of variance of

powdery mildew (Blumeria graminis) infection of the studied winter rye genotypes

\begin{tabular}{cccc}
\hline Variance & $d f$ & $M S$ & $F_{\text {Emp }}$ \\
\hline Genotypes & 232 & 0.047 & $4.53^{* *}$ \\
Error & 466 & 0.010 & \\
\hline
\end{tabular}

**_significance level $\alpha=0.01$ 
Table 3

Average powdery mildew (Blumeria graminis) infection of the studied rye genotypes and their division into homogeneous groups using Duncan's test

\begin{tabular}{|c|c|c|}
\hline $\begin{array}{l}\text { Homogeneous } \\
\text { groups }\end{array}$ & $\begin{array}{l}\text { Range of } \\
\text { variance }\end{array}$ & Lines \\
\hline a & $1-1.3$ & UP77, UP78, UP2, UP76, UP90 \\
\hline b & $1.3-1.63$ & UP2, UP76, UP90, UP113. UP5, UP86, UP89 \\
\hline $\mathrm{c}$ & $1.63-2$ & UP113. UP5, UP86, UP89, UP8, UP84, UP85 \\
\hline $\mathrm{d}$ & $2-2.31$ & UP8, UP84, UP85, UP102, UP224, UP225, UP71, UP72, UP73, UP74, UP75, UP81, UP87, UP91 \\
\hline e & $2.31-2.64$ & $\begin{array}{l}\text { UP102, UP224, UP225, UP71, UP72, UP73, UP74, UP75, UP81, UP87, UP91, UP1, UP100, } \\
\text { UP101, UP111, UP12, UP121, UP124, UP130, UP131, UP132, UP16, UP163, UP17, UP19, } \\
\text { UP194, UP199, UP20, UP201, UP206, UP208, UP211, UP217, UP220, UP223, UP23, UP233, } \\
\text { UP24, UP25, UP30, UP37, UP42, UP55, UP58, UP59, UP6, UP60, UP63, UP66, UP67, UP69, } \\
\text { UP7, UP79, UP83, UP9, UP94 }\end{array}$ \\
\hline $\mathrm{f}$ & $2.64-3$ & $\begin{array}{l}\text { UP1, UP100, UP101, UP111, UP12, UP121, UP124, UP130, UP131, UP132, UP16, UP163, } \\
\text { UP17, UP19, UP194, UP199, UP20, UP201, UP206, UP208, UP211, UP217, UP220, UP223, } \\
\text { UP23, UP233, UP24, UP25, UP30, UP37, UP42, UP55, UP58, UP59, UP6, UP60, UP63, UP66, } \\
\text { UP67, UP69, UP7, UP79, UP83, UP9, UP94, UP10, UP103, UP104, UP105, UP106, UP107, } \\
\text { UP108, UP109, UP11, UP110, UP112, UP114, UP115, UP116, UP117, UP118, UP119, UP120, } \\
\text { UP122, UP123, UP125, UP126, UP127, UP128, UP129, UP13, UP133, UP134, UP135, UP136, } \\
\text { UP137, UP138, UP139, UP14, UP140, UP141, UP142, UP143, UP144, UP145, UP146, UP147, } \\
\text { UP148, UP149, UP15, UP150, UP151, UP152, UP153, UP154, UP155, UP156, UP157, UP158, } \\
\text { UP159, UP160, UP161, UP162, UP164, UP165, UP166, UP167, UP168, UP169, UP170, UP171, } \\
\text { UP172, UP173, UP174, UP175, UP176, UP177, UP178, UP179, UP18, UP180, UP181, UP182, } \\
\text { UP183, UP184, UP185, UP186, UP187, UP188, UP189, UP190, UP191, UP192, UP193, UP195, } \\
\text { UP196, UP197, UP198, UP200, UP202, UP203, UP204, UP205, UP207, UP209, UP21, UP210, } \\
\text { UP212, UP213, UP214, UP215, UP216, UP218, UP219, UP22, UP221, UP222, UP226, UP227, } \\
\text { UP228, UP229, UP230, UP231, UP232, UP26, UP27, UP29, UP3, UP33, UP36, UP38, UP39, } \\
\text { UP4, UP40, UP41, UP43, UP44, UP45, UP46, UP47, UP48, UP49, UP50, UP51, UP52, UP53, } \\
\text { UP54, UP56, UP57, UP61, UP62, UP64, UP65, UP68, UP70, UP80, UP82, UP88, UP92, UP93, } \\
\text { UP95, UP96, UP97, UP98, UP99 }\end{array}$ \\
\hline $\mathrm{g}$ & $3-3.32$ & $\begin{array}{l}\text { UP10, UP103, UP104, UP105, UP106, UP107, UP108, UP109, UP11, UP110, UP112, UP114, } \\
\text { UP115, UP116, UP117, UP118, UP119, UP120, UP122, UP123, UP125, UP126, UP127, UP128, } \\
\text { UP129, UP13, UP133, UP134, UP135, UP136, UP137, UP138, UP139, UP14, UP140, UP141, } \\
\text { UP142, UP143, UP144, UP145, UP146, UP147, UP148, UP149, UP15, UP150, UP151, UP152, } \\
\text { UP153, UP154, UP155, UP156, UP157, UP158, UP159, UP160, UP161, UP162, UP164, UP165, } \\
\text { UP166, UP167, UP168, UP169, UP170, UP171, UP172, UP173, UP174, UP175, UP176, UP177, } \\
\text { UP178, UP179, UP18, UP180, UP181, UP182, UP183, UP184, UP185, UP186, UP187, UP188, } \\
\text { UP189, UP190, UP191, UP192, UP193, UP195, UP196, UP197, UP198, UP200, UP202, UP203, } \\
\text { UP204, UP205, UP207, UP209, UP21, UP210, UP212, UP213, UP214, UP215, UP216, UP218, } \\
\text { UP219, UP22, UP221, UP222, UP226, UP227, UP228, UP229, UP230, UP231, UP232, UP26, } \\
\text { UP27, UP29, UP3, UP33, UP36, UP38, UP39, UP4, UP40, UP41, UP43, UP44, UP45, UP46, } \\
\text { UP47, UP48, UP49, UP50, UP51, UP52, UP53, UP54, UP56, UP57, UP61, UP62, UP64, UP65, } \\
\text { UP68, UP70, UP80, UP82, UP8,, UP92, UP93, UP95, UP96, UP97, UP98, UP99, UP28, UP31, } \\
\text { UP32, UP34, UP35 }\end{array}$ \\
\hline
\end{tabular}

\section{DISCUSSION}

Among the winter rye inbred lines studied, no genotypes highly resistant to powdery mildew have been found. The range of variation in powdery mildew infection of the analyzed inbred lines was from 1 to 3.3. And thus, the genotypes under study varied significantly in respect of susceptibility to infection by powdery mildew. Similar results were obtained by Gó r a 1 [9] in his study of triticale lines, who also reported significant variation of the analyzed lines as concerns their susceptibility to powder mildew. The research carried out by Góral [9] revealed the occurrence of highly resistant lines and cultivars of triticale, whereas in the present study no rye forms were detected in the analyzed material which would be highly resistant to powdery mildew infection. There were only lines tolerant to this pathogen.

The obtained results indicate that powdery mildew represents a serious threat to rye, considering the fact that a great part of the studied lines displayed high 
susceptibility to this pathogen. Of the 233 genotypes, nearly $71 \%$ rye genotypes (165 inbred lines) were included in the last homogeneous group, characterized by the highest susceptibility to powdery mildew infection. In the study material, merely $2 \%$ of the winter rye genotypes were assigned to the first uniform group of the lowest level of infection by powdery mildew. Only two lines, namely UP77 and UP78, were characterized high resistance, equalling 1, i.e. they were tolerant to this pathogen. The lines which belong to the first homogeneous group constitute a source of genes of incomplete resistance to powdery mildew. The introduction of these genes to new cultivars, through their use in breeding programs involving the lines mentioned above, can increase the tolerance of winter rye to the pathogen concerned.

The recorded lack of complete resistance of the winter rye inbred lines and the small percentage of genotypes characterized by low infection with powdery mildew indicate that the material under study did not include effective genes of resistance to this pathogen, which makes it necessary to search for sources of complete resistance among wild rye species such as Secale montanum or Secale kuprianovii [10]. Nowadays, successful introduction of genes of resistance to powdery mildew from other uncultivated species is pursued in the case of common wheat [11-18]. However, one should take into account the possible transfer of many unfavourable traits, particularly lowered fertility and susceptibility to lodging $[19,20]$. And therefore, the sources of resistance should be sought in fertile populations and ones resistant to lodging.

\section{CONCLUSIONS}

Among the genotypes studied, there were no forms entirely resistant to infection by powdery mildew.

Due to their tolerance to the pathogen mentioned, lines UP77 and UP78 represent valuable initial material for acquiring inbred lines of enhanced resistance to powdery mildew (Blumeria graminis) which would be useful in resistant-oriented breeding programmes.

\section{Acknowledgements}

The project was funded by the National Science Centre, Krakow, Poland (Project No. 7773/B/ $\mathrm{P} 01 / 2011 / 40)$.

\section{Authors' contributions}

The following declarations about authors' contributions to the research have been made: concept of study: H.B., A.J., experiments: H.B., A.J., estimation: H.B., writing: H.B., A.J.

\section{REFERENCES}

1. Jorgensen J.H. Erysiphe graminis, powdery mildew of cereals and grasses. Ad. Plant Pathol. 1988; 6: 138-157.

2. Rzepka D., Łapiński M., Bojarczuk J. Odporność na mączniaka prawdziwego (Erysiphe graminis D.C. f. sp. secalis Marschal) mieszańców międzygatunkowych żyta. / The resistance of interspecific rye hybrids to powdery mildew (Erysiphe graminis D.C. f. sp. secalis Marschal). Hod. Rośl., Aklim. Nas. 1990; 34, 5/6, 73-85. (in Polish)

3. Rzepka-Plevnes D., Bojarczuk J. Trwałość odporności na mączniaka prawdziwego (Erysiphe graminis D.C. f. sp. secalis Marschal) w populacjach mieszańców międzygatunkowych żyta. / The persistence of resistance to powdery mildew (Erysiphe graminis D.C. f. sp. secalis Marschal) in populations of interspecific rye hybrids. Hod. Rośl., Aklim. Nas. 1995; 39(6): 51-65. (in Polish)

4. Schlegel R. Rye (Secale cereale L.): A Younger Crop Plant with a Bright Future. [In:] R.J. Singh (ed.), Genetic Resources, Chromosome Engineering, and Crop Improvement: 2006; 365-394. http://dx.doi.org/10.1201/ 9780203489260.ch12

5. Wakuliński W., Zamorski CZ., Nowicki B., Schollenberger M., Mierzwa-Mróz E., Mikulski W. et al. Grzyb Blumeria graminis (DC) Speer poważnym zagrożeniem dla pszenżyta. / Fungus Blumeria graminis (DC) Speer as serious risk for triticale in Poland. Prog. Plant Prot. / Post. Ochr. Rośl. 2005; 45: 505-510. (in Polish)

6. Wakuliński W., Zamorski CZ., Nowicki B. Podatność odmian i linii hodowlanych pszenżyta na porażenie przez Blumeria graminis (DC) Speer. / Susceptibility of triticale breeding lines and cultivars to infection by Blumeria graminis (DC) Speer. Prog. Plant Prot. / Post. Ochr. Roślin 2007; 47: 361-365. (in Polish)

7. B ennett F.G.A. The expression of resistance to powdery mildew infection in winter wheat cultivars. I. Seedling resistance. Ann. Appl. Biol. 1981; 98: 295-303. http://dx. doi.org/10.1111/j.1744-7348.1981.tb00762.x

8. Hsam S.L.K., Zeller F.J. Breeding for powdery mildew resistance in common wheat (Triticum aestivum L.). [In]: R.R. Belanger, W.R. Bushnell, A.J. Dik, T.L.W. Carver (eds). The Powdery Mildews. A Comprehensive Treatise. The American Phytopathologyological Society, 2002; 219-238.

9. Góral T. Ocena odporności rodów pszenicy ozimej i pszenżyta ozimego na fuzariozę kłosów powodowaną przez Fusarium culmorum oraz odporności pszenżyta ozimego na mączniaka prawdziwego (Blumeria graminis) w 2005 roku. / Evaluation of resistance of winter wheat and winter triticale breeding lines to Fusariumhead blight caused by Fusarium culmorum and resistance of winter triticale to powdery mildew (Blumeria graminis) in 2005. Short communication. Biul. Inst. Hod. Aklim. Rośl. 2006; 242: 79-88. (in Polish)

10. Kubicka H. Dziedziczenie cech u żyta (Secale cereale L.). [In:] A.G. Górny (ed.). Zarys Genetyki Zbóż. Tom 1. 
Jęczmień, pszenica i żyto. Wyd. IGR PAN Poznań: 2004; 329-424. (in Polish)

11. Heun M., Friebe B., Bushuk W. Chromosomal Location of the Powdery Mildew Resistance Gene of Amigo Wheat. Phytopathology, 1990; 80: 1129-1133. http:// dx.doi.org/10.1094/Phyto-80-1129

12. Heun M., Friebe B. Introgression of Powdery Mildew Resistance from Rye into Wheat. Phytopathology, 1990; 80: 242-245. http://dx.doi.org/10.1094/Phyto-80-242

13. Jia J., Devos K.M., Chao S., Miller T.E., Reader S.M., Gale M.D. RFLP-based maps of the homoeologous group- 6 chromosomes of wheat and their application in the tagging of Pm12, a powdery mildew resistance gene transferred from Aegilops speltoides to wheat. Theor. Appl. Genet. 1996; 92: 559-565. http://dx.doi.org/ 10.1007/BF00224558

14. Friebe B., Heun M., Tuleen N., Zeller F.J., Gill B.S. Cytogenetically monitored transfer of powdery mildew resistance from rye into wheat. Crop Sci. 1994; 34: 621-625. http://dx.doi.org/10.2135/cropsci1994. 0011183X003400030003x

15. Lutz J., Hsam S.L.K., Limpert E., Zeller F.J. Chromosomal location of powdery mildew resistance genes in Triticum aestivum L. (common wheat). 2. Genes Pm2 and Pm19 from Aegilops squarrosa L. Heredity, 1995; 74: 152-156. http://dx.doi.org/10.1038/hdy.1995.22

16. Jakobson I., Peusha H., Timofejeva L., Järve K. Adult plant seedling resistance to powdery mildew in a Triticum aestivum x triticum militinae hybrid line. Theor. Appl. Genet. 2006; 112: 760-769.

17. Rong J.K., Millet E., Manisterski J., Feldman M. A new powdery mildew resistance gene: Introgression from wild emmer into common wheat and RFLP-based mapping. Euphytica, 2000; 115: 121-126.

18. Shi A.N., Leath S., Murphy J.P. A Major Gene for Powdery Mildew Resistance Transferred to Common Wheat from Wild Einkorn Wheat. Phytopatology, 1998; 88: 144-147. http://dx.doi.org/10.1094/PHYTO.1998.88.2.144

19. Ortelli S., Winzeler M., Winzeler P., Fried M., N o s berger J. Leaf rust resistance gene Lr9 and winter wheat yield reduction. Crop Sci. 1996; 36: 1590-1595. http://dx.doi.org/10.2135/cropsci1996.0011183X0036 00060030x
20. The T.T., Latter B.D.H., Mcintosh R.A., Ellison F.W., Brennan P.S., Fisher J. et al. Grain yield of near isogenic lines with added genes for stem rust resistance. In: Miller T. E., Koebner R.M.D. editors. Proceedings of the 7th International Wheat Genetics Symposium: 1988; 901-906.

\section{Ocena stopnia porażenia mączniakiem prawdziwym (Blumeria graminis f. sp. secalis) żyta ozimego (Secale cereale $\mathbf{L}$.)}

\section{Streszczenie}

Mączniak prawdziwy (Blumeria graminis) $\mathrm{w}$ zimnych i wilgotnych latach powoduje straty w plonie żyta ozimego (Secale cerale L.) sięgające $20 \%$. W celu ograniczenia występowania tej choroby i stosowania środków ochrony roślin zaleca się uprawiać odmiany żyta ozimego odporne lub tolerancyjne na porażenie przez Blumeria graminis. Pierwszym etapem w programach hodowli odpornościowej żyta ozimego jest dobranie odpowiednich komponentów do krzyżowań. Komponenty te powinny charakteryzować się odpornością na porażenie mączniakiem prawdziwym, aby cechę tę przekazać wyprowadzanym nowym genotypom.

W pracy przedstawiono wyniki badań służących wyselekcjonowaniu linii wsobnych żyta ozimego o najmniejszej podatności na porażenie przez Blumeria graminis. Ocenie poddano 233 genotypy żyta ozimego, które inokulowano polową populacją patogena. Stopień porażenia oceniano w skali $0-4$. Następnie wyniki opracowano statystycznie. Badane genotypy podzielono testem Duncana na grupy jednorodne. Wyznaczono 7 grup jednorodnych. Do pierwszej grupy jednorodnej o najniższym stopniu porażenia zaliczono 5 linii wsobnych żyta. Linie te mogą posłużyć jako komponenty do krzyżowań w programach hodowli odpornościowej.

Handling Editor: Elżbieta Weryszko-Chmielewska

This is an Open Access digital version of the article distributed under the terms of the Creative Commons Attribution 3.0 License (creativecommons.org/licenses/by/3.0/), which permits redistribution, commercial and non-commercial, provided that the article is properly cited.

CThe Author(s) 2013 Published by Polish Botanical Society 